\title{
Identity, Otherness, Crime: Detective Fiction and Interethnic Hazards
}

\author{
Caius DOBRESCU \\ University of Bucharest \\ Department of Literary Studies \\ caius.dobrescu@gmail.com
}

\begin{abstract}
The topic of Otherness has been investigated from the point of view of popular culture and popular fiction studies, especially on the basis of the multiracial social environments of the United States. The challenges of addressing real or potential conflicts in areas characterised by an ethnic puzzle are to some extent similar, but at the same time differ substantively from the political, legal, and fictional world of "race." This paper investigates these differences in the ways of overcoming ethnic stereotyping on the basis of examples taken from post-World War II crime fiction of Southern Europe, and Middle East.

In communist and post-communist Eastern Central Europe there are not many instances of mediational crime fiction. This paper will point to the few, although notable exceptions, while hypothesizing on the factors that could favor in the foreseeable future the emergence and expansion of such artistic experiments in the multiethnic and multicultural province of Transylvania.
\end{abstract}

Keywords: crime fiction, ethnicity, race, conflict, body, post-communism, Transylvania

Complex as it may seem for contemporary social and cultural historians, the genre of crime fiction (including both literary and cinematic narratives-Nicol, McNulty \& Pulham 2011) was, for a long time, exclusively limited to the status of popular entertainment (Forshaw 2007). And, in spite of the commitment of cultural studies experts to expose the network of discriminative prescriptions and procedures which allegedly were always silently at work in the mental depths of popular culture (Cohen 2000, Spencer 2006, Rushing 2007, Evans 2009), this type of fiction still remains, in the eyes of numerous members of the public, an unsophisticated way of getting a "good," even if not necessarily "clean" fun. But besides these "learned" and "lay" attitudes, we should also account for a gradual change of the cultural status of crime fiction since World War II, which was due not to undercurrents of the popular psyche, but to the ethical choices and cultural policies of individual authors and other actors of the literary system. 
The main goal of the present undertaking is to estimate the potential of crime fiction to deliver not only usable representations of ethnic "otherness" (that is to say, usable within the ethical framework of a liberal democracy), but also of providing effective symbolic means of mitigating the imaginative stakes always present in ethnic conflicts. This might sound very common to the ears of researchers familiar with the agenda of popular culture studies, and especially of US-focused popular fiction surveys (Bertens \& D'haen 2001). It is a fact that the study of crime fiction is massively dominated by US authors and Americanists. Because of that the theme of the emergence and (real or potential) clash of symbolic collective identities, as illustrated in popular culture genres such as crime fiction is identified with US sensitivities and political priorities, among these, the preeminence of "race" and race conflict.

This cast of mind is, of course, consistent with the historical experience of a self-defined multiracial society, a society in which, quite predictably, the very understanding of multiculturalism tends to be predicated on the "primary" or "basic" experience of racial diversity. I propose that the salience of the study of racial labeling, stereotyping, and antagonisms is both supportive and inhibiting for the research of the articulation of ethnicity in post-WWII crime fiction. And it is so especially if we consider those cultural areas which, like the Middle East, East-Central or Southern Europe, neither see themselves as multiracial, nor could be described as such from any consensual theoretical perspective.

Consequently, the second sequence of my paper will analyze the play between similarities and dissimilarities as far as race and ethnic studies are concerned, on the basis of works generated from within historical situations of mutual violence, hate, and distrust. Analyzing "ethnicity" in the context of crime fiction will, therefore, focus on the measure and manner in which a subtle literary transfiguration of the loci communi of popular imagination is connected with the painful uncertainties, intricacies, and moral blind spots of different regional histories.

The last part of the present paper will concentrate on the relevant developments in communist and especially post-communist Eastern Europe, with some tentative remarks on the possibilities of using crime fiction as an instrument of cultural policy within the Transylvanian multiethnic and multicultural context.

\section{Crime, Conflict, and Inter-Racial Catharsis}

The evolution of detective and crime fiction towards the status of a respectable if not prestigious literary form is closely connected to the transformation of this genre into both a rhetorical instrument and a rhetorical battlefield concerning some of the most pungent polemics of post-WWII United States. The process of cultural upgrading of crime writing was directly influenced by the involvement/ 
intricacy of this type of popular fiction in the 1960s confrontations around the political enfranchising of the African-Americans.

This crucial matter deserves a more extended elaboration, but before approaching it, we should remember that the status of crime fiction had already begun to change before the era of the civil rights movement, with the gradual recognition by the high culture establishment of the significance of authors such as James M. Cain, Dashiell Hammet and Raymond Chandler (Scaggs 2005, Forshaw 2007). Ironically or not, the eye of literary and cultural critics was not caught primarily by the refined puzzles and plots placed in sophisticated British social milieus, such as those invented by the authors congregated in the highbrow Detection Club founded in 1930. It is true that some of these writers enjoyed great popularity, culminating with the fact that the most famous of them, Agatha Christie, has been turned into a global popular culture icon. It is also true that occasionally this socially and morally sanitized type of crime fiction could also produce ethically complex narratives such as G. K. Chesterton's Father Brown novels. But the main interest of the aesthetically-minded readers was rather channeled towards the roman noir, the "hardboiled" creations that, on the one hand, were exploring violent and insecure fringe social milieus, and, on the other, were exposing the subterranean streams and complicity/cupidity networks supposed to connect the social heights with the social underground, but also, within the individual psyche, the superego with the unconscious (Cohen 2000).

In other words, crime fiction was brought into the light of cultural significance not by its logical refinements, but by its alleged capacity to resound with the "darkest" layers of human behavior, therefore moving within a general flow of aesthetic naturalism and cultural pessimism with upbeat fin-de-siècle Nietzschean origins. To wrap the argument up, we should conclude that, before its manifest shift of cultural status in the militant and utopian 1960s, the form of detective and crime fiction was already permeated by a "decadent" sensitivity typified by a disquieting osmosis between social and bodily (or psychic) decay.

This indirect manner of thematizing corporeality in its essential fragility and "morbidity" (the infliction of actual death-producing violence upon the fictional victims being at the centre of a complex network of bodily allusions and suggestions concurring in the general impression of a "somatized" or "visceralized" universe) paved the way for the thematization of race in the US crime fiction since the 1960s. Aesthetically, the naturalistic expressionism derived from the fin-de-siècle décadence represented a kind of formative mould, an Urgrund of the roman noir. In point of the social imaginary, the fictional structures of crime fiction could be construed as connecting: a) the disquieting representation of the fluid, transgressive nature of the "body" (peaking on the recurrence of a morally shocking motive such as the Blutschande, the "blood sin," which is to say "incest"-Braun 1989) with b) the ideological concept of 
"race" issued from a centuries-long philosophical debate in the English-speaking world and acquiring a new political momentum in the US, in the aftermath of WWII (Spencer 2006).

To this contiguity, suggesting the mysterious ways of an ongoing process of thematic osmosis, bears witness the contemporaneity of two novels both turned eventually into cult motion pictures. The first one is Robert Bloch's 1959 Psycho (brought to a world prominence by the 1960 filmic adaptation of Alfred Hitchcock, a work of art seen as a cornerstone in the history of post-WWII cinema), notoriously presenting an extreme case of schizophrenia with incestuous undertones. The second novel having a huge cultural impact was the 1965 In the Heat of the Night authored by John Ball (and turned into a film in 1967 by Norman Jewison-a production which collected no less than five Academy Awards), which presents the dramatic confrontation between the blatant racial prejudice of a South Carolina small town community shuttered by a brutal murder with sexual content, and the dignified and intellectually sophisticated Virgil Tibbs, an African American Philadelphia homicide investigator. The later character, masterfully embodied by Sidney Poitier, became a symbol of the civil rights movement and an icon of global popular culture (Browne 1986, 95-104).

This new political identity nurtured itself on the symbolic ambivalences of the investigative procedures traditionally represented by crime fiction. The very nature and apparatus of investigation have to do with unraveling secrets, and the thrill and quality of the process mirrors the complexity, depth and embeddedness of the secrets to be exposed. If this holds true, then we might presume that the 1960s search for artistic vehicles to carry an emancipatory message to a mass audience (an attempt actually echoing, consciously or not, experiments made by the Soviet Avant-Garde with the propaganda potential of different popular genres-Stites 1989), intersected an inner tendency of creating ever more powerful "revelatory" literary effects. As a consequence of this interaction the scope of the represented investigation procedures constantly widened from the identification of definite evil "entities," from individual perpetrators and clearly-categorized misdeeds and moral scourges, to the unveiling of pernicious networks of interests, of conspiracies of silence, of the dark, brutal, and "polymorphously perverse" underground of an apparently free and opulent society. We should not forget that this brand of militant crime fiction developed in the cultural vicinity of the radical utopianism of the 1960s, which was thriving on conspiratorial fantasies (Pipes 1997, Evans 2009). The aesthetical acumen of the politically empowered crime fiction lie in the subtlety of revealing discriminatory habits of the heart so deeply engrained that they have become the second nature of a society otherwise priding itself on its egalitarian traditions.

The political avatar of crime fiction was also characterized by the ostentatious enhancement of the dramatic element that had always been present in the structure 
of the genre. Actually, a murder case, until solved, brackets the very possibility of civilized society, puts it in question, lends it to prangs of chronic doubt. The very structure of a crime narrative has the potential of calling into question the social statuses and identities of the agents involved in it, therefore generating a clash of "naked" passions and interests closely reminding of the state of crisis posited by Mikhail Bakhtin as essential to the social function of fiction (Bakhtin made these allegations consequently to the application of his theory of narrative “carnivalization” on Dostoyevsky's major novels-Bakhtin 1984).

The articulation of an aesthetics of graduality cum ambiguity with an aesthetics of explosion, unveiling the "true," even if impure motivations behind the actions of the involved parties inserted crime fiction quite "naturally" in the grand narrative of the Civil Rights Movement ignited in the 1960s. The main impact of this thus-reconstructed genre can be documented on the lines of climacticallycathartically representing (and eventually attempting to exorcise the "demons" of) racial conflicts in the social and mental context of the Southern US (Hawkins 1995, Reddy 2003). Powered by the same social momentum, crime fiction had also served to promote feminism into the mainstream popular culture (Munt 1994, Erickson Johnsen 2006).

But it is time now to narrow the scope of our investigation and to estimate the degree and the effects of the impact of this revitalized, ideologized and aesthetically and intellectually empowered popular genre on inherently multicultural areas marked by ethnic, rather than racial conflicts.

\section{Crime and Chiasm: Ethnicity as Ethical Imbroglio}

In the militant US 1960s interracial confrontation was seen as a psychodrama and as an archetypal conflict, since race was supposed to be absolute evidence, rooted in a "fundamental" somatic reality. In Europe, as opposed to America or the colonial world, the symbolic encapsulation of a racial difference had been arbitrary connected with a deliriously somatized representation of the otherness of the Jew and of "Jewishness." Unlike the history of racial representations projected by Americans of European descent on African Americans, in continental, and especially in Central and Eastern Europe, the power (and eventual empowerment) of hostile racial representations did not come from any somatic "evidence," but, on the contrary, from the paranoid anxiety of not being able to tell the allegedly hostile Other from one's own racial "kin." The Jews were construed as threatening especially because, in point of social "face" and cultural affiliation, "they" were almost undistinguishable from "us” (Schoeps \& Simon 1995).

Actually the process of somatization of ethnic cultural differences began in Central and Eastern Europe at a much earlier date. It was closely connected 
with the German-based birth of the ethnic nation, built around intense Blut und Boden representations which have been associated by cultural critics with psychoanalytical leanings on the imagery of a pantheistic eroticism of sorts (Mosse 1985, Parker et al. 1992, Sieg 2002, Doan \& Garitty 2010). The "voice of blood" was intensified by the ambiguously seductive approach of intense representations of carnal passion. Even the Blutschande (understood as incestuous passion) already evoked in the present context could count, within this imaginary pattern, as a powerful, almost ecstatic metaphor of "brotherly love" so deep that it eluded any ethical code, any moral taboo (Braun 1989). Within this frame, the hostile Other insinuating itself within the autoerotic body of the nation could be construed (under the inescapable influence of the modern physiological imagination) as an "infectious disease" (Schoeps \& Simon 1995).

Placed against this imaginary configuration, the narrative patterns of "crime" (i.e. murder) could only have acquired paranoid symbolisms of exorcism and self-purification. This connection was already exposed and analyzed by Siegfried Kracauer, through the study of the ambiguous interaction of the emotional violence-prone expressionist cinema with the process of concocting the anxieties and psychic depression of the German post-WWI society into an ideology of vengeful and racist nativism (Kracauer 1959).

Therefore, it took a very long and complicated evolution, marked by the genocidal tragedies of WWII, to displace the symbolism of crime-as-racialscapegoating and to instrumentalize it into an analytic narrative structure. This is to say a structure which does not function as a mantra meant to build up tension to the threshold of an overflow of negative emotions directed against a demonized fictional perpetrator bearing a "blood stigma" (that is to say, a narrative totally coextensive with the rhetorical mechanisms of what was scientifically defined as "hate speech"-Kirk Whillock \& Slayden 1995, Cesereanu 2003). On the contrary, the narrative structure of a crime investigation would rather accommodate different forms of narrative ralenti, i.e. various stylistic devices meant to "delay" the action and allowing for the development of (and thereby thematizing) reflexive doubt. In this new era of conjunction between crime fiction and the ethnic imagination, the emotional elements of the narrative are not directed against, but made to support the process (or the figuring of the process) of analytic thought.

The construction of ethnicity in post-WWII continental crime fiction gradually went the way of epitomizing the reflexive moments of an "investigation," but not without a previous mid-station that unconsciously implied the reversed replication of the Nazi crime fiction recipe. That is to say, the uncritical rerun of narrative schemes in which the perpetrator was not actually revealed within the fictional framework, but through the instrument of fiction, in an ideological context in which "racial" guilt was attributed a priori. In the aftermath of WWII continental Western European crime fiction incorporated a Manichean epic 
representation of Evil that mixed radically polemic images of the Nazi "other," and traditional hostile stereotypes of the "Germans" and "German-ness" (Rollyson, Abbott \& Davies 2008).

West Germany itself had no problems of joining the firm condemnation of the Nazi past, but its position was evidently much more uncomfortable as far as the Germanophobic ethnic stereotyping was concerned. This specific position generated some of the first European significant attempts of articulating "criminal" investigative narrative structures with a discriminative construction of the ethnic: the novels of Hans Hellmut Kirst, Fabrik der Offiziere (Officer Factory, 1960adapted for the screen in the same year by the German director Franz Wisbar, and a second time in 1989, as a mini-series written, produced and directed by Wolf Vollmar) and Die Nacht der Generale (The Night of the Generals, 1962-adapted for the screen, quite symbolically, as a 1967 British-French production under the direction of Anatole Litvak, a Jewish-American of Ukrainian descent). Both novels had to do with the process of Vergangenheitsbewältigung, the "struggle to come to terms with the past," by presenting the moral corruption of the Nazi system through the vast complicity in covering brutal murders perpetrated by SS and Wehrmacht officials, at the same time with the stubbornness of investigators inspired if not by a moral abhorrence of the Nazi ideology, at least by a general sense of justice (Lieutenant Karl Krafft, respectively the Major Grau). In a narrative twist quite unspecific for murder mysteries, both Krafft and Grau are assassinated in order to keep the veil of silence over perpetrators held in high Nazi esteem.

Kirst's novels point to the most important cultural effect that the structure of crime fiction could create on ethnic processes of self-definition and selfidentification. The crime narrative structure is not oriented towards articulating symbolic elements into a substantive, charismatic representation of a collective identity, but it rather follows the lines of cleavage within the allegedly innate moral solidarity of the ethnic nation. Dramatic tension does not build in a selfrevelatory cohesive experience, but comes from the vibration of ethical selfdoubt. The murdering of the murder investigators turns them into the symbolic forerunners (or involuntary, "accidental" founding fathers) of a community created not through "natural" empathy but around a strong commitment to transcendental ethical imperatives.

More than that, in the second and most famous of the above-mentioned Kirst novels, The Night of the Generals, the represented investigation knits together two epochs (the perpetrator is tracked first in the 1940s, in German-occupied Warsaw and Paris, then in the 1960s France), but also two sleuths representing two nations with a hate-loaded common history: the German major Grau and, taking up his inquiry two decades after his physical disappearance, the French police inspector Morand. This time-loop with empathetic bi-national overtones points to an essential transformation of the dramatic function of crime fiction: 
while associated with the activism of the US 1960s, it was styled as a kind of battle of the giants, but in continental post-WWII Europe, its function was rather to dissolve the ideologically mummified ties of undisputed ethnic nationalist solidarity, to arouse one's critical skepticism towards the moral cohesiveness and justifications of the goals of one's own ethnic camp, and, finally, to substantiate the precept that deadly dangers are necessarily not "before the gates," and that the Other encapsulated as the enemy could prove to be, at the end of the day, more humane than one's own traditionally proclaimed "blood brothers."

A later phase of the ethnically concerned crime fiction has to do with another geographical area, Southern Europe, and with the historical moment when the post-WWII economic wonder, somehow delayed in this part of the continent, began to bear social and cultural fruits. The détente following the sharp ideological polarisation of the 1960s created forms of crime fiction in which ethnicity and drama, even if co-present in the narrative frame, are not necessarily co-extensive. Ethnicity is presented neither as a blessing, nor as a curse, but rather as a pervasive atmosphere, having to do not with great narratives of heroic sacrifice, but rather with the "small" family and community histories and benign cultural features of everyday life, such as, for instance, gastronomy.

The proper embodiment of these cultural and literary evolutions is to be found in the series of novels of Manuel Vázquez Montalbán treating the abrupt changes underwent by the province of Catalonia in the post-Franco era form the perspective of private investigator Pepe Carvalho, a sophisticated libertine and gourmet. Written in Spanish, even if placed for the most part in Barcelona, but, imbued with innumerable cultural and multicultural local intricacies, Montalbán's poetic and ironic novels are miles away from any display of Catalan irredentism. Following in his steps-in the most overt manner, since his investigator is named, after his Spanish peer and forerunner, commissario Montalbano-the Italian author Andrea Camilleri uses subtle detectivistic imbroglios in order to present an image of Sicily and "Sicilianness" quite remote from the one traditionally derived form the neo-realist social dramas. The Montalbano novels are styling Southern Italian ethnicity as a refined form of savoir vivre.

A most interesting example is Petros Markaris, the creator of commissioner Kostas Haritos, the leading character of a detective series picturing the networks that bind together the political, social, cultural and crime scenes of contemporary Athens. Ethnicity is present in the Kostas Haritos books as a motive and as a general atmosphere (thereby suggesting the specificity of the Greek cultural mix within the European concert) very much in the spirit of the other two abovementioned Mediterranean crime authors, Montalbán and Camilleri. But Greece's organic ties to the unsettled Balkans and the Middle East seem to make the references to contemporary or historical regional traumas definitely unavoidable. The investigative structure sets, on occasions, the representation of ethnicity in 
connection to the impact on the Greek society of the waves of refugees or illegal economic migrants coming from ex-Communist Balkan countries (Markaris 2007).

At other times, the present is haunted by the specters of an only apparently remote history, having to do, for the most, with the heavy legacy of the GreekTurkish relationships. In Long, Long Ago (2008; the German translation accessible to me was titled Die Kinderfrau / The Nanny, 2009), an old woman, who during her Istanbul youth babysitted the offspring of wealthy Greek families, returns from Greece, where she came as a refugee after the 1955 anti-Greek riots, to Istanbul, in order to dispense to people who had influenced her life, Greeks and Turks alike, rewards and punishments, both in the form of home-baked pita breads. The difference being that those destined to the wrongdoers prove to be impregnated with a poison causing a degrading and painful death. On holiday in Istanbul, Haritos is consigned by his superior in Athens to collaborate with the local police forces in order to handle a situation that might cause diplomatic tensions. The detective tracking reveals a complicated past in which the ethical boundaries do not overlap with the ethnic ones, a past dominated by numerous ethno-ethical chiasms (the "close" Other, and the distant, if not averse "kin"). The story also opens a window, through Haritos' relationship to his young, Western-educated Istanbul co-investigator, to the paradoxes and the fragile balances of present-day Turkey, a social diversity that appears as difficult to manage, understand and contain as Greece's own.

An interesting instance for the transforming of the crime fiction genre in an intellectual instrument for the problematization of ethno-national identity/ otherness is to be found in the hotbed of the Near East. For this area, we have first of all to consider the novels of the Israeli author Batya Gur featuring the Jerusalem police detective Michael Ohayon. Deeply entrenched in a conflict perceived as a battle for survival, the Israeli society is, nevertheless, depicted, with complete transparence and honesty, in all its complexities, doubts, and, last but not least, inner culture wars. For instance, in Murder in Jerusalem (2006), the last novel of the Ohayon series (which actually was interrupted by Batya Gur's untimely death), the investigative structure and the symbolisms of "crime" are used in order to reveal the violent mutual hate opposing the liberals who occasionally tend to side with the Palestinian cause, at least as far as the human rights abuses of the Israeli army are concerned, and the religious fundamentalists, with their radical suspicion against the secular state and society. Besides, the search for the factual truth to which the leading character and his team are totally committed reveals a universe of ethical nuances, choices and blind spots which implicitly pleads for a nation construed not around a substantive ethnicity, but as a community of interrogation and doubt.

If we are to consider the situation from the Palestinian perspective, the partial equivalent of Batya Gur's undertaking could be considered the Matt Beynon Rees's Palestine Quartet, which features the exploits of the amateur detective 
Omar Yussef, a professor of history and a former OLP militant who has grown totally disappointed with the Palestinian authority technically governing the Gaza strip, but incapable of putting an end to the anarchic violence of the fanaticized, corrupt, and abusive paramilitary. In spite of their complexity and subtle mélange of irony and intense drama, I call Beynon Rees's works a partial equivalent of the scrutiny of Israeli society styled as crime fiction by Batya Gur because Beynon Rees is not a Palestinian or Arab, but a Welsh author, writing in English for a predominantly English-speaking audience.

If we were to find among genuine Arab authors an example of using crime fiction for raising complex problems of identity building, the choice would almost inescapably go to Yasmina Khadra. This being the feminine pen name of Mohammed Moulessehoul, a former Algerian army officer who currently resides in France. In his novel Morituri (1997, adapted for the screen in 2007 as a FrenchAlgerian production under the direction of Okacha Touita), Khadra reflects, through his leading character Superintendent Brahim Llob, on the Algerian paradox of juxtaposing an extremely bloody civil war between the secular government and the Islamic fundamentalists with an all-pervasive ideological ambiguity and with a very nuanced spectre of everyday moral choices.

\section{Crime Fiction and the Post-Communist Nation: a Match in the Making?}

In communist Eastern Europe, though crime fiction had a larger scale, spectrum, and network of supporters than it is acknowledged by the Western world, the development of the genre has been significantly distorted by ideological restraints. To which it should be added that the nature of social life under a closely controlled economy did not leave many options for elaborate criminal plots (Segel 2008, 137-142). In the first phase of its development, Eastern European crime fiction was drilled by essentialist representations of the "enemies of the socialist state" lumping together the surviving imagery of the war propaganda (the Nazis and Fascists, under different guises, were pictured as a direct threat to society long after the end of WWII - a habit to some extent connected with the ease of labeling as such any form of inner dissent or opposition to the human rights abuses of the communist regimes), the standard Cold War representation of the great anti-socialist conspiracy of the capitalist world (a fantasy which directly engendered a large variety of fictional spies passionately interested in the technological breakthroughs of the allegedly most progressive form of society), and the traditional Soviet-backed gallery of stereotyped "enemies from within" (i.e. the free rider, the parasite, the greedy black-marketer, etc.). 
In time, crime fiction gradually moved towards more complex motivations and characters. Given its popular and commercial genealogy, it also acquired the status of a tacit cultural mediator between the austere mainstream socialist culture and a burgeoning literary free market revolving around the genuine psychological or intellectual thrill. That is to say that crime fiction thrived as far as it could present itself as an innocent hobby very similar in nature with other consecrated socialist forms of leisure such as solving crosswords puzzles or chess problems.

As far as the ethnic stakes are concerned, they might have been marginally present in the forms of minor motives, but, in the communist times, crime fiction as such seems to have provided neither a significant ideological vehicle for nationalist propaganda, nor an especially effective instrument of literary subversion. With the possible exception of somewhat dissent authors like the East-German Wolfgang Hilbig (Segel 2008, 141-2) or the Czech Josef Škvorecký. The latter's famous Lieutenant Boruvka series contains elements of social satire, though most notably in its fourth and final part published after Škvorecký's expatriation to Canada ([1980] 1991).

If we are to consider the matter sociologically, we should say that the premises for the process that makes the object of the present study, the transmogrifying of crime fiction into a tribune for publically problematizing ethnic and interethnic representations, seem to have been ideally reunited only after the fall of the communist system. The tensions and conflicts generated partially by the new living conditions, partially by the revival of pre-communist ideological conflicts, were partial to an unexpected comeback of crude ethnic positive and negative stereotyping, as much as to a revival of pre-communist nationalist and even antisemitic ideologies (Tismăneanu 1998, Shafir 1999).

In spite of these "favoring" conditions (to which we could add a certain pre-communist Central European tradition of noir), and in spite of a manifest interest of the public in the crime genre, examples of creative uses of this literary structure in order to promote a critical attitude towards ethnic stereotyping and a debate around substantive identities are for the time being rather scarce. One could account for a momentary conversion to detective fiction of an established ex-dissenting author like the Czech Pavel Kohout, in his Hvězdná hodina vrahů/ The Widow Killer ([1995] 1998), which takes a detective investigation as the pretext for exploring the moral and psychological tensions roaming between Czechs, Germans, and Jews, in the very last days of the Nazi occupation of Prague. Or the recent attempt of the Hungarian author Vilmos Kondor of entering the English speaking crime fiction scene with his 2008 Budapest Noir (translated into English 2012), set in 1936 and revolving around the intricacies (e.g. the possible connection to the original emergence of radical ideologies that tend to re-emerge in the post-communist era) of the killing of a young Jewish woman. 
But the most accomplished and internationally acclaimed crime fiction project aspiring simultaneously to literary sophistication and to a complex and critical view of the region's convoluted ethnic identities and histories, is the Eberhard Mock series of Polish author Marek Krajewski. Set in the interbellum German city of Breslau, which is going to become, after WWII, the Polish city of Wrocław, Krajewski's novels follow his leading character, a detective with the Breslau police, through the imbroglios of plots which bring together classical elements of the hardboiled detective story (more often than not exaggerated in an ironical and livresque manner) with the most sensitive topics of the German-Polish mutually guilt-ridden history (e.g. Krajewski [2006] 2008). To his credit, Krajewski is in no way attempting to tell his stories from the "official" Polish point of view: following the tribulations of his German detective, who is essentially a lonely rider and a cynic of the Sam Spade breed, he does not refrain from addressing the most uncomfortable aspects of the Polish pressures for the German depopulation of Breslau after the war, or of the Polish implication in the repression of the local Jewish population.

\section{Transylvanian Perspectives?}

The conclusion of this survey is meant to keep us within the atmosphere of present day Eastern Europe, and especially that of an area so very complex from the point of view of embedded ethnicities, ambiguous heritages, silent resentments, as the province of Transylvania. To the best of my knowledge, there were no attempts to tackle the ethnic complexities and (blatant lack of) interethnic communication of this area with the instruments of as powerful a popular genre as crime fiction, the possible exception being Katalin Varga, a film narrative conceived by British director Peter Strickland released in 2009.

The eponymous character of this film is a woman from the rural Szeklerland (in the South-Eastern part of Transylvania) who was brutally raped by a Roma man, with the help of a second perpetrator, and who, as a consequence of this, bore a son. Realising the truth after many years, her lawful husband banishes her. Katalin Varga decides to overcome her condition of social outcast by seeking revenge over the two fatidic culprits. In a cinematic language that, as it was largely noticed, reminds of the slowness and ritualism of Béla Tarr, Peter Strickland follows a pattern of conflict quite similar not to the reflexivity and nuance with which the substantive ethnic representations are tested in the crime fiction examples cited above, but rather to the cathartic intensity of the racial conflicts featured in the 1960s US crime fiction.

Apart from his artistic endeavors, we could say that with Katalin Varga Strickland is not much closer to understanding the social and cultural complexities 
of the Transylvanian ethnic landscape than was his forerunner Bram Stoker. But it is possible to hypothesize that his rather dim perception of the real tensions nested within the local multiculturalism is also a consequence of the traditional strategy of the Transylvanian ethnic communities to avoid each other as much as possible, to act, at least at an imaginary level, as if the other did not actually exist.

The tragedy of Katalin Varga is emotionally intense and convincing: the woman kills the man who had passively assisted to her ordeal, only to discover later on that the one who had actually raped her, and the actual father of her son was not the horrid brute she had always projected in her imagination. The revelation of her identity and story triggers the suicide of the rapist's wife, while Katalin is, in the end, caught and brutally suppressed by the relatives of the man whose life she had previously taken. But no matter how effective aesthetically or emotionally, the mixture of archaic sacrificial ritualism and moral paradoxes created by the British director is in no way touching on the real conundrums of the Hungarian-Romanian relationships in Transylvania.

Strickland's movie could be construed as an incentive for a real effort of converting the structures of crime fiction into credible tools of exploring the long durée of the interactions bewteen the two communities and between their more often than not conflicting imageries. We might also ask the question whether, given the fact that both literary and cinematic crime fiction have proved to a reasonable extent their capacity of producing public debate and of affecting mentalities, the emergence of such forms of ethical-aesthetical mitigation could not be promoted by means of a definite cultural policy. If, for instance, different types of public institutions, local, regional, national or European, in different possible combinations and with the essential support of non-governmental civic and cultural organizations and of private cultural entrepreneurs, could sponsor long-term editorial projects with an agenda of interethnic communication through the innovative use of consecrated popular literary genres, such as crime fiction.

But, of course, this should be the subject of a distinct social and academic argument.

\section{Works cited}

Allen, Tim and John Eade (eds.). 1999. Divide Europeans: Understanding Ethnicities in Conflict. The Hague: Kluwer Law International.

Bakhtin, M. M. 1984. Problems of Dostoevsky's Poetics. Ed. and trans. by Caryl Emerson. Minneapolis: University of Minnesota Press.

Bertens, Hans and Theo D'haen (eds.). 2001. Contemporary American Crime Fiction. New York: Palgrave MacMillan.

Bloch, Robert. 1959. Psycho. New York: Simon \& Schuster. 
Braham, Persephone. 2004. Crimes against the State, Crimes against Persons: Detective Fiction in Cuba and Mexico. Minneapolis - London: University of Minnesota Press.

Braun, Christina von. 1989. Die schamlose Schönheit des Vergangenen: zum Verhältnis von Geschlecht und Geschichte. Frankfurt: Verlag Neue Kritik.

Browne, Ray B. 1986. Heroes and Humanities: Detective Fiction and Culture. Bowling Green, Ohio: Bowling Green State University Popular Press.

Ball, John. 1965. In the Heat of the Night. New York: Harper \& Row.

Cesereanu, Ruxandra. 2003. Imaginarul violent al românilor. [The Romanians' Imagery of Violence.] Bucharest: Humanitas.

Cohen, Michael. 2000. Murder Most Fair: The Appeal of Mystery Fiction. Cranbury N.J. - London: Associated University Press.

Doan, Laura and Jane Garitty (eds.). 2010. Sapphic Modernities: Sexuality, Women and National Culture. New York: Palgrave Macmillan.

Dunn, Seamus and T. G. Fraser (eds.). 1996. Europe and Ethnicity: the First World War and Contemporary Conflict. New York: Routledge.

Erickson Johnsen, Rosemary. 2006. Contemporary Feminist Historical Crime Fiction. New York: Palgrave MacMillan.

Evans, Mary. 2009. The Imagination of Evil: Detective Fiction and the Modern World. London - New York: Continuum.

Fischer-Hornung, Dorothea and Monika Mueller (eds.). 2003. Sleuthing Ethnicity: the Detective in Multiethnic Crime Fiction. Cranbury N. J. - London: Associated University Press.

Forshaw, Barry. 2007. The Rough Guide to Crime Fiction. London: Rough Guides - Penguin Books.

Gur, Batya. 2006. Murder in Jerusalem: A Michael Ohayon Mystery. Translated into English by Evan Fallenberg. New York: HarperCollins Publishers.

Hawkins, Darnell F. (ed.). 1995. Ethnicity, Race, and Crime: Perspectives across Time and Place. Albany: State University of New York Press.

Kawana, Sari. 2008. Murder Most Modern: Detective Fiction and Japanese Culture. Minneapolis - London: University of Minnesota Press.

Khadra, Yasmina. 2003 Morituri. Translated into English by David Herman. New Milford: Toby Press.

Kirk Whillock, Rita and David Slayden (eds.). 1995. Hate Speech. Thousand Oaks, Calif.: Sage Publications.

Kirst, Hans Hellmut. 1960. Fabrik der Offiziere. [Officer Factory.] Munich: Desch Verlag.

-. 1962. Die Nacht der Generale. [The Night of the Generals] Munich: Desch Verlag. 
Kohout, Pavel. [1995] 1998. The Widow Killer. Translated into English by Neil Bermel. New York: St. Martin's Press.

Kondor Vilmos. [2008] 2012. Budapest Noir: A Novel. Trans. Paul Olchváry. New York - London: HarperCollins.

Kracauer, Siegfried. 1959. From Caligari to Hitler: A Psychological History of the German Film. New York: Noonday Press.

Krajenbrink, Marieke and Kate M. Quinn (eds.). 2009. Investigating Identities: Questions of Identity in Contemporary International Crime Fiction. Amsterdam - New York: Textext: Studies in Comparative Literature, no. 56.

Krajewski, Marek. [2006] 2008. Death in Breslau. Translated into English by Danusia Stok. London: MacLehose Press.

Markaris, Petros. [2008] 2009. Die Kinderfrau. [The Nanny.] Translated into German by Michaela Prinzinger. Zürich: Diogenes.

—. 2007. Balkan Blues. Translated into German by Michaela Prinzinger. Zürich: Diogenes.

Mosse, George L. 1985. Nationalism and Sexuality: Respectability and Abnormal Sexuality in Modern Europe. New York : H. Fertig.

Munt, Sally R. 1994. Murder by the Book?: Feminism and the Crime Novel. New York: Routledge.

Nicol, Bran, Eugene McNulty and Patricia Pulham (eds.). 2011. Crime Culture: Figuring Criminality in Fiction and Film. London - New York: Continuum.

Parker, Andrew, Mary Russo, Doris Sommer and Patricia Yaeger (eds.). 1992. Nationalisms \& Sexualities. New York: Routledge.

Pipes, Daniel. 1997. Conspiracy: How the Paranoid Style Flourishes and Where It Comes From. New York: Free Press.

Priestman, Martin (ed.). 2003. The Cambridge Companion to Crime Fiction. Cambridge etc.: Cambridge University Press.

Reddy, Maureen T. 2003. Traces, Codes, and Clues: Reading Race in Crime Fiction. New Brunswick, NJ: Rutgers University Press.

Rollyson, Carl, Anthony Abbott and L. P. Davies (eds.). 2008. Critical Survey of Mystery and Detective Fiction. Revised edition. Volume 1. Pasadena, California Hackensack, New Jersey: Salem Press.

Rushing, Robert A. 2007. Resisting Arrest: Detective Fiction and Popular Culture. New York: Other Press.

Scaggs, John. 2005. Crime Fiction. London - New York: Routledge.

Schneider, Stephen Jay (ed.). 2004. Horror Film and Psychoanalysis. Cambridge etc.: Cambridge University Press.

Schoeps, Julius H. and Herman Simon (eds.). 1995. Dreyfus und die Folgen. Berlin: Edition Hentrich. 
Segel, Harold B. 2008. The Columbia Literary History of Eastern Europe: Since 1945. New York: Columbia Univeristy Press.

Shafir, Michael. 1999. The Mind of Romania's Radical Right. In The Radical Right in Central and Eastern Europe since 1989, ed. Sabrina P. Ramet, 213-232. University Park: Penn State University Press.

Sieg, Katrin. 2002. Ethnic Drag: Performing Race, Nation, Sexuality in West Germany. Ann Arbor: University of Michigan Press.

Škvorecký, Josef. [1980] 1991. The Return of Lieutenant Boruvka: A Reactionary Tale of Crime and Detection. Translated and adapted by Paul Wilson. New York: Norton.

Spencer, Stephen. 2006. Race and Ethnicity: Culture, Identity and Representation. New York: Routledge.

Stites, Richard. 1989. Revolutionary Dreams. Utopian Vision and Experimental Life in the Russian Revolution. New York - Oxford: Oxford University Press.

Tismăneanu, Vladimir. 1998. Fantasies of Salvation: Democracy, Nationalism, and Myth in Post-Communist Europe. Princeton, NJ: Princeton University Press. 